\title{
Plasma ultrafiltrable magnesium in insulin dependent diabetics
}

\author{
I R GUNN,** EILEEN BURNS $\dagger$ \\ From the Departments of *Chemical Pathology and †Medicine, St James's University Hospital, Leeds
}

SUMMARY Plasma ultrafiltrable $\left(\mathrm{Mg}_{\mathrm{UF}}\right)$ and total magnesium concentrations were measured in 60 insulin dependent diabetics and compared with values in an age matched control group. Although the diabetic patients had lower plasma albumin concentrations $(p<0.05)$, both ultrafiltrable and total magnesium concentrations were significantly decreased by $6.8 \%$ and $7 \cdot 6 \%$, respectively, compared with those of the controls $\left(\mathrm{p}<0.001\right.$ ). In the diabetic group $\mathrm{Mg}_{\mathrm{UF}}$ varied inversely with fasting plasma glucose $(r=-0.269, \mathrm{p}<0.05)$. In 14 patients with significant hypomagnesaemia, fasting plasma glucose concentration was higher $(p<0.01)$ and the diabetes was of shorter duration $(\mathrm{p}<0.05)$ than in 46 patients with an $\mathbf{M g}_{\mathrm{UF}}$ in the control range. The fasting urinary magnesium creatinine ratio was greater in the diabetic patients $(p<0.05)$. Patients with retinopathy did not have lower plasma magnesium values than those without retinopathy.

There have been several reports of low plasma magnesium concentrations in patients with insulin dependent diabetes mellitus, ${ }^{1-8}$ and some suggest that the consequences may include increased risk of cardiovascular complications of the disease. ${ }^{2459}$ Twenty five to $30 \%$ of plasma magnesium, however, is bound to proteins-mainly albumin. Binding of magnesium to albumin depends on the plasma $\mathrm{pH}$. Plasma protein and $\mathrm{pH}$ disturbances are not unusual in diabetes, and it is conceivable that total magnesium concentrations which have been reported are not an accurate reflection of free plasma magnesium. In the absence of $\mathrm{pH}$ disturbances it may be possible to allow for plasma albumin variations by adjusting the measured total magnesium, ${ }^{10}$ but an alternative approach is direct measurement of the free plasma fraction. We measured plasma ultrafiltrable magnesium concentrations and, using two different analytical methods, total plasma magnesium concentrations in insulin dependent diabetics and control populations.

\section{Material and methods}

The control group consisted of 58 ( 23 men, 35 women) healthy laboratory staff and outpatients who had been referred for a glucose tolerance test, which was subsequently shown to be normal with no glycosuria. The patients comprised 60 (34 men, 26 women) type I diabetics who had volunteered to take part in the study as outpatients. Subjects taking diuretic treatment and those with a plasma creatinine concentration of more than $120 \mu \mathrm{mol} / 1$ were excluded. Permission for the study was granted by the local ethical committee.

\section{SAMPLING PROCEDURES}

All venous blood samples were taken with minimal venous stasis after the subject had fasted for 10 hours overnight. The subjects were seated for the sample but had been ambulant immediately before sampling.

Samples for ionised calcium and ultrafiltrable magnesium were maintained at in vivo $\mathrm{pH}$ by transferring the venous blood to fill completely a $12.5 \mathrm{ml}$ lithium heparin tube and immediately proceeding to centrifuge, and then separating the plasma to perform the analysis.

Urine samples were obtained after a 10 hours overnight fast, the subject having discarded the first urine voided on rising.

\section{ANALYTICAL METHODS}

Ultrafiltrates of plasma were prepared by transferring $1.1 \mathrm{ml}$ plasma to fill completely an Amicon Centrifree Micropartition device that was immediately spun at 
Table 1 Clinical and biochemical variables in controls and diabetic patients

\begin{tabular}{|c|c|c|c|c|c|}
\hline \multirow{3}{*}{$\begin{array}{l}\text { Age (years) } \\
\text { Duration of } \\
\text { diabetes }\end{array}$} & \multicolumn{2}{|c|}{$\begin{array}{l}\text { Controls }(n=58) \\
\text { Mean }(S D)\end{array}$} & \multicolumn{2}{|c|}{$\begin{array}{l}\text { Patients }(n=60) \\
\text { Mean }(S D)\end{array}$} & \multirow{2}{*}{$\begin{array}{l}P \text { value } \\
\text { NS }\end{array}$} \\
\hline & $39 \cdot 3$ & $(13 \cdot 8)$ & $34 \cdot 6$ & $(12.9)$ & \\
\hline & & & $13 \cdot 2$ & $(7 \cdot 9)$ & \\
\hline $\begin{array}{l}\mathrm{Mg}_{\mathrm{UF}} \\
\mathbf{M g} \text { (atomic }\end{array}$ & $0.575^{*}$ & $(0 \cdot 040)$ & 0.536 & $(0.045)$ & 0.0002 \\
\hline absorption) & $0.800^{*}$ & $(0.053)$ & 0.739 & $(0 \cdot 060)$ & $<0.0001$ \\
\hline Mg (calmagite) & 0.889 & $(0.058)$ & 0.825 & $(0.063)$ & $<0.0001$ \\
\hline $\mathrm{Ca}++7 \cdot 4$ & $1 \cdot 189$ & $(0.031)$ & 1.175 & $(0.034)$ & $<0.05$ \\
\hline Total calcium & $2 \cdot 366$ & $(0 \cdot 100)$ & $2 \cdot 345$ & $(0.089)$ & NS \\
\hline & $7 \cdot 383$ & $(0.027)$ & $7 \cdot 381$ & $(0.027)$ & \\
\hline Albumin $(g / l)$ & $46 \cdot 4$ & $(2 \cdot 7)$ & $45 \cdot 1$ & $(3 \cdot 4)$ & $<0.05$ \\
\hline $\mathrm{HbA}_{1}(\%)$ & $6 \cdot 83^{*}$ & $(2 \cdot 41)$ & $10 \cdot 42$ & $(2 \cdot 56)$ & $<0.0001$ \\
\hline $\begin{array}{l}\text { Glucose } \\
\text { Creatinine }\end{array}$ & & $(1.02)$ & $12 \cdot 28$ & $(6 \cdot 11)$ & $<0.0001$ \\
\hline (ummol/l) & $83 \cdot 3$ & $(19 \cdot 4)$ & $79 \cdot 1$ & $(14 \cdot 1)$ & NS \\
\hline Cholesterol & $6 \cdot 16^{*}$ & $(1 \cdot 16)$ & 6.03 & $(1.29)$ & NS \\
\hline Triglyceride & $0 \cdot 75^{*}$ & $(0.38)$ & 0.83 & $(0.49)$ & NS \\
\hline Urinary & & & & & \\
\hline $\begin{array}{l}\text { magnesium: } \\
\text { creatinine ratio }\end{array}$ & $0 \cdot 229$ & $(0.097)$ & 0.285 & $(0.144)$ & $<0.05$ \\
\hline
\end{tabular}

${ }^{*} \mathrm{n}=27$. Units are $\mathrm{mmol} / \mathrm{l}$, unless stated; $\mathrm{p}$ value calculated by unpaired $t$ test.

$2250 \mathrm{~g}$ for 15 minutes at a sample temperature of (26 SD 2$)^{\circ} \mathrm{C}$ in a Wifug fixed angle centrifuge. Full details of the technique have been described elsewhere. ${ }^{11}$ Magnesium concentration in the ultrafiltrate was measured without delay using a Pye Unicam SP192 atomic absorption spectrophotometer. The intrabatch coefficient of variation for the whole technique was $1.2 \%$ at $\mathrm{Mg}_{\mathrm{UF}}$ values of $0.60 \mathrm{mmol} / \mathrm{l}$.

Total magnesium concentrations were measured by atomic absorption (Pye Unicam SP192) and an automated method entailing complexing with Calmagite (American Monitor Parallel).

Ionised calcium concentrations and $\mathrm{pH}$ were measured on a Radiometer ICA-1 and adjusted to $\mathrm{pH} 7.4$ by the formula built into that machine. Total plasma calcium was measured by cresolphthalein complexone; albumin by an automated short incubation time BCG method; creatinine by a kinetic Jaffé reaction; and cholesterol and triglycerides by automated enzymatic methods.

Glycosylated haemoglobin was measured by affinity electrophoresis, and glucose by a glucose oxidase method (Beckman).

\section{Results}

In the control group the only significant difference between men and women was in plasma creatinine concentration (mean $95.4 v 75.3 \mu \mathrm{mol} / \mathrm{l}$ ), so that the predominance of men in the diabetic group was considered not to have biased the comparison. Table 1 shows that there was no significant difference in the ages between the two groups. The total plasma mag- nesium concentration was lower in the diabetic patients by both analytical methods, and despite a significantly lower albumin concentration and a tendency towards acidaemia, the mean $\mathbf{M g}_{\mathrm{UF}}$ concentration was correspondingly decreased by $6.8 \%$. Fourteen $(23 \%)$ of the diabetic patients also had $\mathrm{Mg}_{\mathrm{UF}}$ values of more than $2 \mathrm{SD}$ below the mean of the control group. The urine magnesium:creatinine ratio was higher in the diabetic group as a whole $(p<$ $0 \cdot 05$ ), but the 14 patients with significant hypomagnesaemia had a lower ratio than the 46 others ( $p$ $<0.02$ ).

No significant differences were observed between the mean of plasma creatinine, triglyceride, cholesterol and total calcium concentrations, but the ionised calcium value was slightly, but significantly, lower in the diabetic patients $(\mathrm{p}<0.05)$.

Table 2 summarises some clinical and biochemical characteristics of the 14 diabetic patients with significant hypomagnesaemia. The most striking features were the higher fasting plasma glucose concentration and the shorter duration of the disease. There was also a tendency towards lower plasma calcium and albumin concentrations in this group. In the diabetic population as a whole $\mathbf{M g}_{\mathrm{UF}}$ correlated negatively with fasting plasma glucose concentration $(r=$ $0 \cdot 269$ ), but not with HbA. Total magnesium did not have a significant correlation with plasma glucose, but it did correlate positively with plasma albumin concentration $(r=0.284, p<0.05)$. The regression equation for total magnesium (measured by atomic absorption) on plasma albumin was:

$$
\mathrm{Mg}(\mathrm{mmol} / \mathrm{l})=0.534+(\operatorname{albumin}(\mathrm{g} / \mathrm{l}) \times 0.0046)
$$

Table 3 shows characteristics of patients with and without retinopathy. In those with mild eye signs the only difference of note was the longer duration of the

Table 2 Characteristics of patients with significant hypomagnesaemia

\begin{tabular}{|c|c|c|c|}
\hline \multirow{6}{*}{$\begin{array}{l}\text { Glucose }(\mathrm{mmol} / \mathrm{l}) \\
\text { HbA }(\%) \\
\text { Total calcium } \\
\quad(\mathrm{mmol} / \mathrm{l}) \\
\mathrm{Ca}^{++} 7 \cdot 4 \\
\quad(\mathrm{mmol} / \mathrm{l}) \\
\text { Albumin }(\mathrm{g} / \mathrm{l}) \\
\text { Age (years) } \\
\text { Duration of } \\
\text { diabetes (years) } \\
\text { Urinary magnesium } \\
\text { creatinine } \\
\text { (mmol/l) }\end{array}$} & $\begin{array}{l}\text { Magnesium } \\
<2 S D \text { below } \\
\text { control mean } \\
(n=14) \\
\text { Mean }(S D)\end{array}$ & $\begin{array}{l}\text { Magnesium } \\
\text { within } \\
\text { control range } \\
(n=46) \\
\text { Mean }(S D)\end{array}$ & \multirow{2}{*}{$\begin{array}{l}P \text { value } \\
<0.01 \\
\text { NS }\end{array}$} \\
\hline & $\begin{array}{ll}16.1 & (6 \cdot 2) \\
10.8 & (3.2)\end{array}$ & $\begin{array}{ll}11.1 & (5.6) \\
10.5 & (2.5)\end{array}$ & \\
\hline & $2 \cdot 318(0.066)$ & $2.353 \quad(0.094)$ & NS \\
\hline & $\begin{array}{ll}1.164(0.027) \\
44.2 & (3.2) \\
30.0 & (8.6)\end{array}$ & $\begin{array}{ll}1.179 & (0.035) \\
45.3 & (3.4) \\
36.3 & (13.9)\end{array}$ & $\begin{array}{l}\text { NS } \\
\text { NS } \\
\text { NS }\end{array}$ \\
\hline & $9.0 \quad(3.5)$ & $(8 \cdot 7)$ & $<0.01$ \\
\hline & $0.200(0.082)$ & $0.310 \quad(0.150)$ & $<0.02$ \\
\hline
\end{tabular}


Table 3 Clinical and biochemical variables in patients with and without retinopathy

\begin{tabular}{|c|c|c|c|c|c|c|}
\hline \multirow[b]{2}{*}{$\begin{array}{l}\text { Duration (years) } \\
\text { Urea (mmol/l) } \\
\text { Creatinine (umol/l) } \\
\text { Albumin }(\mathrm{g} / \mathrm{l}) \\
\text { Total magnesium }(\mathrm{mmol} / \mathrm{l}) \\
\mathrm{Mg}_{\mathrm{UF}}(\mathrm{mmol} / \mathrm{l}) \\
\mathrm{HbA}_{1}(\%)\end{array}$} & \multicolumn{2}{|c|}{ No retinopathy } & \multicolumn{2}{|c|}{ Retinopathy } & \multicolumn{2}{|c|}{ Severe retinopathy } \\
\hline & $\begin{array}{l}10 \cdot 9 \\
5 \cdot 53 \\
78 \cdot 5 \\
45 \cdot 3 \\
0.731 \\
0.533 \\
10.1\end{array}$ & $\begin{array}{l}(5 \cdot 7) \\
(1 \cdot 33) \\
(12 \cdot 0) \\
(3 \cdot 1) \\
(0.063) \\
(0 \cdot 045) \\
(2 \cdot 6)\end{array}$ & $\begin{array}{l}20 \cdot 3 \dagger \\
6 \cdot 06 \\
80 \cdot 3 \\
44 \cdot 6 \\
0.755 \\
0.542 \\
11 \cdot 1\end{array}$ & $\begin{array}{l}(9 \cdot 6) \\
(1.92) \\
(18.0) \\
(3.9) \\
(0.051) \\
(0.044) \\
(2 \cdot 3)\end{array}$ & $\begin{array}{l}27 \cdot 4 \dagger \\
7.43^{*} \\
88 \cdot 9 \\
43.6 \dagger \\
0.757 \\
0.550 \\
13.5 \dagger\end{array}$ & $\begin{array}{l}(7 \cdot 3) \\
(2 \cdot 48) \\
(22 \cdot 4) \\
(2 \cdot 6) \\
(0.057) \\
(0.049) \\
(1 \cdot 5)\end{array}$ \\
\hline
\end{tabular}

${ }^{*} p<0.01$ compared with values in group with no retinopathy; $\nmid p<0.001$ compared with values in group with no retinopathy.

diabetes than in those with normal retinae. Patients with more severe haemorrhages and exudates and with new blood vessel formation had been diabetics for longer still, but in addition, had, on average, a higher plasma urea and $\mathrm{HbA}_{1}$ concentration and lower plasma albumin value. There were no significant differences in plasma magnesium and lipid fractions between the three groups.

\section{Discussion}

We have shown for the first time that free plasma magnesium concentrations are low in diabetic patients treated with insulin. Twenty three per cent of patients had an $\mathrm{Mg}_{\mathrm{UF}}$ greater than 2 SD below the mean of the control population, compared with $25 \%$ found by Mather et $a l^{3}$ and $40 \%$ by McNair et al, ${ }^{12}$ who measured total plasma magnesium concentration. In common with the findings of those studies, we found that low plasma magnesium concentrations were most commonly seen in patients with a high fasting plasma glucose value, but did not seem to be particularly related to metabolic control of the condition as assessed by glycosylated haemoglobin measurement. The 14 patients with significant hypomagnesaemia had a much higher average fasting glucose $(16.1 v 11.1 \mathrm{mmol} / \mathrm{l})$, while there was negligible difference between the $\mathrm{HbA}_{1}$ concentration of these 14 and the 46 patients with magnesium concentrations in the control range. In the whole group $\mathrm{Mg}_{\mathrm{UF}}$ varied inversely with fasting plasma glucose concentrations $(p<0.05)$, but not with $\mathrm{HbA}_{1}$ values. Total magnesium did not correlate significantly with glucose.

Mather et $a l^{13}$ showed that total plasma magnesium concentrations vary inversely with plasma glucose during daily fluctuations in individual diabetics, but their analysis was impeded by the complication of fluctuations in plasma albumin concentrations. Our demonstration of a strong correlation between $\mathbf{M g}_{U F}$ and glucose at a population level adds weight to the evidence that this is a true relation.

The mechanism of such a relation is not entirely clear. It may be that administration of exogenous in- sulin is responsible for the fall in magnesium, perhaps by uptake of magnesium into cells ${ }^{14}$ or increased urinary excretion of magnesium. ${ }^{12}$ It has been shown, however, that total plasma magnesium concentrations after insulin administration tend to rise rather than fall in diabetic patients. ${ }^{13}$

One attractive possibility is that the hypomagnesaemia per se, perhaps through suboptimal performance of enzyme systems through which the action of insulin is mediated, renders control of diabetes more difficult. This has been shown in recovery from ketoacidosis, ${ }^{15}$ but it may apply to more stable diabetics. Such a mechanism would certainly account for the inverse relation between plasma magnesium and glucose concentrations and is also compatible with the association of increased urinary excretion of magnesium with an increased daily dose of insulin. ${ }^{12}$

There is evidence of tissue depletion of magnesium in insulin dependent diabetes. Erythrocyte magnesium has been shown to be depleted, ${ }^{58}$ as has bone content, ${ }^{16}$ although other work has reported no difference in erythrocyte, leucocyte, and muscle magnesium content. ${ }^{1718}$

The reason for the hypomagnesaemia in diabetic patients is almost certainly increased renal loss of magnesium, probably because hyperglycaemia inhibits tubular reabsorption of magnesium and calcium. ${ }^{19}$ Thus there may be a cycle in which glycosuria leads to hypomagnesaemia, which in turn leads to difficulty in controlling the diabetic condition, and thus increased likelihood of further glycosuria. This study confirms that increased urinary magnesium excretion occurs in diabetics, but we found the urinary magnesium:creatinine ratio to be lower in the 14 patients with hypomagnesaemia than in the other 46 , and overall, a significant positive correlation between plasma magnesium and urine magnesium:creatinine ratio $(p<0.02)$. This is in contrast to the finding of McNair et $a^{12}$-increased urinary magnesium with lower plasma magnesium concentrations.

We concur with others ${ }^{2}$ that significant hypomagnesaemia predominates in young diabetic patients with a shorter duration of the disease. This finding makes it difficult to explain the reports from other cross sectional studies that lower plasma mag- 
nesium values are present in diabetics with retinopathy. ${ }^{245} \mathrm{We}$ did not find this to be the case. The only distinguishing feature of our patients with retinopathy was the longer duration of disease, and in those with severe retinopathy, higher $\mathbf{H b A}_{1}$ and plasma urea values. A recently published longitudinal study $^{20}$ has shown that duration of the disease is by far the most important influence on the development of retinopathy, with minor contributions from long term glycaemic control, serum triglycerides, and age. Unfortunately, the authors did not include measurement of plasma magnesium.

Plasma magnesium values tend to increase,$^{311}$ and albumin values to decrease ${ }^{21}$ with increasing age in control populations. Thus it is very difficult to draw logical conclusions from cross sectional studies measuring total plasma magnesium, when hypomagnesaemia seems to occur in patients with recent onset of diabetes, and retinopathy in those with disease of long duration.

A follow up study of the development of complications in young diabetic patients with hypomagnesaemia is mandatory to determine whether hypomagnesaemia is a risk factor for diabetic retinopathy or other complications. We have shown that despite significant hypoalbuminaemia in diabetic patients, there is a strong correlation between ultrafiltrable and total plasma magnesium, and there is a similar mean percentage decrease in the ultrafiltrable and total plasma magnesium concentrations compared with those of control groups. Therefore measurement of total plasma magnesium should be adequate in the planning of a longitudinal study.

\section{References}

1 Stutzman FL, Amatuzio DS. Blood serum magnesium in portal cirrhosis and diabetes mellitus. J Lab Clin Med 1953;41:215-9.

2 McNair P, Christiansen C, Madsbad S, et al. Hypomagnesaemia, a risk factor in diabetic retinopathy. Diabetes 1978;27:1075-7.

3 Mather HM, Nisbet JA, Burton GH, et al. Hypomagnesaemia in diabetes. Clin Chim Acta 1979;95:235-42.
4 Ceriello A, Giugliano D, dello Russo P, Passariello N. Hypomagnesaemia in relation to diabetic retinopathy. Diabetic Care 1982;5:558-9.

5 Fujii S, Takemura T, Wada M, Akai T, Okuda K. Magnesium levels in plasma, erythrocyte and urine in patients with diabetes mellitus. Horm Metab Res 1982;14:161-2.

6 Ewald U, Gebre-Medhin M, Tuvemo T. Hypomagnesaemia in diabetic children. Acta Paediatr Scand 1983;72:367-71.

7 Canagaratna MCP. Serum magnesium levels in diabetes mellitus. Ceylon Med J 1984;29:109-11.

8 Vanroelen WF, van Gaal LF, van Rooy PE, de Leeuw IH. Serum and erythrocyte magnesium levels in type I and type II diabetics. Acta Diabetol Lat 1985;22:185-90.

9 Anonymous. Hypomagnesaemia and diabetic retinopathy. [Editorial]. Lancet 1979;i:762.

10 Kroll MH, Elin RJ. Relationships between magnesium and protein concentrations in serum. Clin Chem 1985;31:244-6.

11 Gunn IR. Measurement of plasma ultrafiltrable magnesium at in vivo $\mathrm{pH}$. Submitted for publication.

12 McNair P, Christensen MS, Christiansen C, Madsbad S, Transbol IB. Renal hypomagnesaemia in human diabetes mellitus: its relation to glucose homeostasis. Eur J Clin Invest 1982;12:81-5.

13 Mather HM, Levin GE, Nisbet JA, Hadley L A-A, Oakley NW, Pilkington TRE. Diurnal profiles of plasma magnesium and blood glucose in diabetes. Diabetologia 1982;22:180-3.

14 Ratzmann GW. On the insulin effect on the magnesium homeostasis. Exp Clin Endocrinol 1985;86:141-5.

15 Moles KW, McMullen JK. Insulin resistance and hypomagnesaemia: case report. $\mathrm{Br}$ Med J 1982;285:262.

16 De Leeuw I, Vertommen J, Abs R. The mineral content of the trabecular bone of diabetic subjects. Diabetologia 1976;12:386.

17 Mather HM, Levin GE. Magnesium status in diabetes. Lancet 1979;i:924.

18 Levin GE, Mather HM, Pilkington TRE. Tissue magnesium status in diabetes mellitus. Diabetologia 1981;21:131-4.

19 Lemann J Jr, Lennon EJ, Piering WR, Prien EL Jr, Ricinati ES. Evidence that glucose ingestion inhibits net renal tubular reabsorption of calcium and magnesium in man. $J$ Lab Clin Med 1970;75:578-85.

20 Weber B, Burger W, Hartmann R, Hovener G, Malelus R, Oberdisse $U$. Risk factors for the development of retginopathy in children and adolescents with type I (insulin-dependent) diabetes mellitus. Diabetologia 1986;29:23-9.

21 Ritchie RF. Specific Proteins. In: Henry JB, ed. Clinical diagnosis and management by laboratory methods. Philadelphia: WB Saunders, 1979.

Requests for reprints to: Dr IR Gunn, Department of Chemical Pathology, St James's University Hospital, Leeds LS9 7TF, England. 